\title{
Chapter 1 \\ Between Origin and Destination: German Migrants and the Individual Consequences of Their Global Lives
}

\author{
Marcel Erlinghagen, Andreas Ette, Norbert F. Schneider, and Nils Witte
}

\subsection{Introduction}

Global migration shapes modern societies. There are 272 million international migrants worldwide, with Europe and North America still representing the major regions of destination (UN 2019). In most of the economically highly developed countries in these two regions, international migration has become the central demographic factor shaping population dynamics and politically, migration is of fundamental concern today not only for international relations, it also forms one of the basic national lines of division (cf. Castles et al. 2014).

From this traditional perspective, global migration shapes modern societies through immigration causing social transformations. But global migration shapes modern societies in hitherto unnoticed ways, namely through the international mobility of these affluent societies' own citizens. During the twentieth century, international migration was mainly understood as immigration into economically highly developed welfare states. This has changed over the course of recent decades and these very countries are meanwhile understood as both receiving and sending countries making them important sources of international mobility (cf. Favell et al. 2007; van Dalen and Henkens 2013). Alongside the increasing volume of international migration originating from these countries, we are witnessing an increasing internationalisation of individual life courses of these countries' citizens. Thanks to the globalisation of communication and transport, episodes of living abroad have become the norm for increasing numbers of these welfare states' populations. According to the Eurobarometer, one in ten Europeans has lived and worked in

\footnotetext{
M. Erlinghagen ( $\square)$

Institute of Sociology, University of Duisburg-Essen, Duisburg, Germany

e-mail: marcel.erlinghagen@uni-due.de
}

\author{
A. Ette $(\bowtie) \cdot$ N. F. Schneider $\cdot$ N. Witte \\ Federal Institute for Population Research, Wiesbaden, Germany \\ e-mail: andreas.ette@bib.bund.de; post@bib.bund.de; nils.witte@bib.bund.de
}


another country in the past (European Commission 2019). Particularly for the younger cohorts, 'global lives'-either in the form of temporary stays abroad or permanent settlement in another country-are biographical opportunities unseen by former generations. Unfortunately, we know little about who these internationally mobile people are. Why are they moving abroad and leaving their home countries, which provide them with good economic opportunities, high living standards, and well-established welfare states? We know even less about the consequences of international mobility for individual life courses. What effects do global lives have on individual professional careers or family life and how do these new biographical opportunities affect the societies in the origin countries?

From an individual perspective, international mobility may increase personal competencies because migration experiences potentially increase available "mobility capital" (Kaufmann et al. 2004), "intercultural capital" (Pöllmann 2013), "mobility competencies" (Rüger et al. 2013), or "transnational human capital" (Gerhards and Hans 2013). Many countries increasingly teach their citizens how to be mobile: Today, stays abroad are a formal requirement in many academic curricula. The yearly number of international students originating from North America and Western Europe studying abroad has increased from 481,000 in the year 2000 to 746,000 in the year 2019 and the Erasmus+ program of the European Union sent 853,000 Europeans to study, train, or volunteer abroad in the year 2018 alone (UIS 2020; European Commission 2019). Also for the demand side-the employer perspective-soft skills and tacit knowledge gained from international mobility are of increasing importance. Previous international experiences and stays abroad have become part of many job posting prerequisites (Gerhards et al. 2017). Overall, international migration has become a common part of individual careers in many economically highly developed welfare states and access to transnational resources is said to be an important determinant of social status and life chances (cf. Beck 2009; Faist 2016; Schneider et al. 2002; Weiß 2005). There is indeed some evidence that the availability of transnational human capital is a relevant precondition for successful social, political, and economic participation in an increasingly globalised world (e.g. Cresswell 2006; Diez Medrano 2014; Jacob et al. 2019). Thus, we can assume that the "mobility turn" (Urry 2007) has far-reaching consequences for social inequalities. While this may be convincing at the theoretical level, there are few empirical data that would enable the empirical assessment of such theoretical perspectives. As a consequence, we know rather little about the consequences of the increasing international migration for individual lives (Willekens et al. 2016).

This volume is a direct response to this lack of knowledge about the emigration from economically highly developed countries and the consequences international experiences and temporary stays abroad have for the life course of mobile individuals. Taking Germany as a paradigmatic case study for an economically highly developed country, all chapters in this volume are based on the German Emigration and Remigration Panel Study (GERPS). This new data infrastructure was established to learn more about this form of international mobility. It complements national surveys by adding existing international linkages of an otherwise ostensibly sedentary population. 
In the remainder of this chapter, we develop a conceptual framework for investigating the consequences of international migration. Incorporating recent debates in migration studies, it argues that individual consequences are not only a question of migrants' integration into destination societies. Rather, the consequences of international mobility should also be studied by comparing migrants with the non-mobile population of the country of origin. Equally, the consequences of international mobility have to be analysed as results of specific trajectories in individual life courses during the migration process. Second, the chapter presents German emigration and remigration-for both theoretical and practical reasons-as particularly well suited case studies to analyse international migration from economically highly developed welfare states. Finally, we separate different dimensions of the life course to systematically study the individual consequences of international migration and provide an outline of the book contents and its chapters.

\subsection{Towards a New Conceptual Framework for Migration Studies}

Migration studies are not well equipped for the analysis of international migration from economically highly developed welfare states. The lack of theoretical development and the interdisciplinary fragmentation of studies about these mobile populations are major reasons for this unsatisfactory state of research. International movements from affluent countries are rarely studied through the lens of established migration theories but treated as sui generis cases of international experiences. Consequently, one is confronted with detailed studies about business or self-initiated expatriates (e.g. Andresen et al. 2015; Habti and Elo 2019; McNulty and Brewster 2017), the international mobility of professionals and the highly skilled within multinational enterprises (e.g. Findlay and Li 1998; Peixoto 2001), as well as the migration of transnational professionals and economic elites (e.g. Harrington and Seabrooke 2020; Pohlmann 2009). Apart from economic migration, there are specialised studies about academic migration and international students (e.g. Ackers and Gill 2008; Bilecen and van Mol 2017), mobility caused by a search for a better lifestyle, and privileged migration linked with the retirement transition (e.g. Benson and O'Reilly 2009; Fauser 2020).

The constant development of new concepts and definitions about our research subject is a welcome sign of a lively and dynamic academic exchange. However, compartmentalising a phenomenon might also hamper scientific progress and we propose that international migration from economically highly developed welfare states be studied within a more encompassing framework that incorporates established theories in migration studies. Building on recent debates in migration studies (e.g. Amelina and Faist 2012; FitzGerald 2012; Guveli et al. 2016), we propose the "destination-origin-migration approach" (DOM) as a new conceptual framework for migration research. Its basic premise perceives emigration and remigration as 
events with far-reaching short-, medium-, and long-term consequences for the life course. Consequently, migration should result in various transformation and adaptation processes in the lives of internationally mobile individuals. It proposes studying the individual consequences of international migration along three spatio-temporal reference units (cf. Pries 2010, p. 131): (1) the population in the destination country, (2) the population in the origin country, and (3) along the individual migration process and life course.

Destination perspective: The destination country is a central spatial reference unit for investigations of the consequences of migration. In classical migration research, individual consequences of migration have been analysed mainly from the perspective of integration or assimilation into the receiving society, relying on interpersonal comparisons between immigrants and the native population (e.g. Alba and Nee 1997; Berry 1997; Heath and Cheung 2007; Portes and Zhou 1993). Obviously, destination countries play a crucial role for the definition of opportunities for immigrants. Although international migrants from economically highly developed welfare states-and in the context of this volume German migrants in particular-are potentially less likely to face discrimination and racialised stereotypes in their destination countries than many other immigrant groups are, evidence suggests that privileged migrants also struggle with stereotypes (e.g. Hainmueller and Hiscox 2010; Helbling 2011). Consequently, the questions of conventional integration research are also relevant for understanding the immigration experiences of German citizens. Do German migrants make efforts at cultural, social, and even political integration in their countries of destination? How do processes of integration develop and how do stays intended as temporary evolve into more permanent settlement? How do structures and opportunities of destination countries moderate individual consequences? These destination country characteristics are likely to shape the short- and long-term consequences of migration. Analytically, research following the destination country perspective examines, for example, the influence of the varying institutional contexts of reception in the different host societies on the consequences of migration for the life course of migrants. It regularly adopts multilevel approaches (cf. DiPrete and Forristal 1994; Snijders and Bosker 2011) to analyse the embeddedness of individuals in structuring social conditions of the life course (e.g. Luthra et al. 2018; Norris and Inglehart 2012; Wright and Bloemraad 2012).

Origin perspective: In the wake of classic integration and assimilation theory, empirical research usually compares natives and groups from various origins in several dimensions of integration. This approach to integration has been criticised for treating integration like a contest between ethnic groups competing for achievement in their destination country (FitzGerald 2014). The first expansion of such a destination perspective, which focuses on integration and assimilation only, points to a different spatial reference: the society in the country of origin (e.g. Baizán et al. 2014; Zuccotti et al. 2015). In this perspective, the living conditions of migrants are compared to the living conditions of the spatially non-mobile population of their home country (sometimes also called "stayers"). This additional spatial reference unit raises a different set of questions. Rather than comparing 
achievements of migrants from various countries of origin, it compares biographies of the internationally mobile with the biographies of non-mobile persons. How are careers affected by international migration? What are the consequences of moving abroad-either temporarily or permanently-for family formation? How do social relationships in the origin country shape emigration but also remigration processes? This origin perspective has recently gained importance and is described as "dissimilation from origins" (Guveli et al. 2016) or just "dissimilation" (FitzGerald 2012). This additional spatial reference unit not only enables investigating the selectivity of migrants compared to non-migrants regarding, for instance, their socio-demographic characteristics, their employment, their partnership, or their health. Analytically, it is better understood as a kind of a counterfactual (Morgan and Winship 2015) where stayers are a crucial control group for the evaluation of individual outcomes of migration. From this perspective, migration is conceptualised as a treatment resulting in individual transformation and adaptation processes (e.g. Braun and Arsene 2009; Erlinghagen 2011; McKenzie et al. 2010; Nikolova and Graham 2015).

Migration perspective: The third reference unit of the destination-originmigration approach is temporal. From this perspective, consequences of international migration are understood as intra-personal transitions and mobilities. Instead of dealing with contested understandings of integration, international migration is conceptualised as an event in the life course with potential consequences for the individual. From a life-course perspective, international migration is a dynamic, open, and multi-dimensional process and offers, again, a different perspective on the consequences of international migration. How do events in the economic or family dimension of the life course impact the migration process? What consequences do different durations of the stay abroad have on the economic returns of migration after remigration? What consequences does the initiative of one person to become internationally mobile have on significant others like their partner or children? Life course analysis has recently developed into an adequate theoretical framework for both qualitative migration research (e.g. Latcheva and Herzog-Punzenberger 2011; Nohl et al. 2014) and quantitative migration research (e.g. Geist and McManus 2008; Kley 2011; Mulder 1993). It principally stresses that the consequences of migration can be better understood if previous migration decisions and past migration experiences are considered. Furthermore, it highlights existing interdependencies between different life domains. That makes the approach particularly apt to investigate, for example, family and employment conditions and their relationship with migration behaviour. Finally, the life course approach enables researchers to recognise the mutual dependencies of the life courses of interacting individuals (e.g. Elder 2003; Mayer 2009). This third research perspective focuses on the migration process itself and asks for changes in various life domains and how these changes are connected with the migration process (e.g. Fuller 2015; Kogan and Weißmann 2013; Windzio and Aybek 2015; Wingens et al. 2011). Additionally, the temporal reference unit, migration, is particularly sensitive for different durations of migration. Migration research is too often predicated on the iconic and antiquated image of migrants who board a steamboat and leave their home country for good. However, 
and not least in times of globalisation, stays abroad are often transitory and migration may proceed in unforeseen ways. The implication is that migration today is not a singular event but a chain of several episodes. Migration biographies increasingly include several temporary stays abroad of different lengths interrupted by remigration or onward migration processes resulting in complex and oscillating mobility behaviours (Findlay et al. 2015). Although theoretical concepts underlining the transnational character of migrant lives thrive (Levitt and Jaworsky 2007), empirical research still struggles to capture temporary, transitional, repeat, circular, or liquid forms of migration (e.g. Constant and Zimmermann 2011; Engbersen et al. 2010).

In conclusion, the DOM approach provides a conceptual framework that integrates different strands of previous migration research. It combines more traditional perspectives on the integration and incorporation of migrants in their destination countries with more recently stressed perspectives comparing migrants with the population in their origin country and the intra-personal developments during the individual migration process. DOM offers a new prism that aims to guide a comprehensive investigation of the individual consequences of international migration.

\subsection{The Case for German Emigration and Remigration}

Besides the theoretical fragmentation discussed above, the dearth of suitable data constitutes a second reason for the unsatisfactory state of research about international migration from economically highly developed welfare states. Internationally mobile persons are a rare and hard-to-reach population and the collection of individual level data is a very complex and ambitious enterprise (Kalton and Anderson 1986; Lavrakas 2008). In response, qualitative studies have started to fill this gap by contributing detailed studies on specific groups of international migrants from economically highly developed welfare states. These include international students, highly skilled professionals, or retirees and their privileged migration experiences (e.g. Carlson 2013; Favell 2008; Hayes 2014). This resulted in a scattered state of research missing the bigger picture of international migration between economically highly developed welfare states. Quantitative research, however, for a long time struggled to come up with adequate research designs and sampling frames. From the perspective of the origin country, existing surveys regularly fail to cover international migration processes in an adequate manner because their sampling frame is usually restricted to national borders. Emigrants are omitted as soon as they move abroad because the event of border crossing simultaneously marks the event of leaving the target population. From the perspective of the destination country, the situation is not much better. Although recent decades have seen significant progress through the establishment of specific migrant surveys in many major countries of destination, these data collection initiatives usually focus on major source countries of migration and therefore regularly neglect migrants from economically highly developed countries (e.g. Diehl et al. 2015; Prandner and Weichbold 2019; see also Ette et al. 2021b in this volume). Despite this lack of data, there are several 
exceptions that investigate emigration in prosperous welfare states. These include, for example, classic immigration countries like the United States or Australia (e.g. Dashefsky and Woodrow-Lafield 2020; Hugo 2006; Klekowski von Koppenfels 2014) as well as many European countries like Austria, Denmark, France, Germany, or the Netherlands (e.g. Beck and Weinar 2017; Ette and Sauer 2010; Kauppinen et al. 2019; Scheibelhofer 2018; van Dalen and Henkens 2013), and also some first cross-nationally comparative analyses (King and Williams 2018; Recchi and Favell 2009; Recchi 2014) but all with significant restrictions concerning their sampling frames and data bases.

All chapters in this volume are based on a new data infrastructure because informative data that allow for the examination of the individual consequences of international migration from economically highly developed countries are generally scarce. The German Emigration and Remigration Panel Study (GERPS) provides detailed information about more than 11,000 internationally mobile German citizens. Its research methodology facilitates the analysis of the individual consequences of international mobility from the three perspectives of the destination-origin-migration approach through two major design features.

First, the study follows a longitudinal design and combines the collection of retrospective biographical data about the situation before the migration event with panel data to study the individual consequences of global lives. Second, GERPS applies a multi-sited design studying migration in both the origin and destination countries. The study was developed in close alignment with the Socio-Economic Panel (SOEP) as the longest running panel survey in Germany. The SOEP provides information about the internationally non-mobile population and facilitates analyses of the consequences of international migration (cf. Ette et al. 2021b in this volume).

At least four reasons advocate the establishment of this new data infrastructure in Germany. First, Germany is a well-suited representative for the group of economically highly developed welfare states since it is one of the world's leading economies with a comparatively low poverty rate and moderate inequality. Among broad measures of wellbeing, Germany offers a high standard of living, a stable democracy, and a highly developed welfare state. When it comes to public social spending, Germany ranks eighth among OECD countries behind France, Finland, and Sweden (OECD 2019). At the same time, the German economy is strongly globalised and export oriented. Experiences abroad have become a priority in the educational system but also for the labour market where the international mobility of workers plays an important role for the prosperity and innovation of German companies (Adick et al. 2014; Lauterbach et al. 2017). Surrounded by European member states, the European Union defines an institutional framework of free movement which governs a large fraction of German emigration (Recchi 2015; Boswell and Geddes 2011). The case selection enables explorations of how this unparalleled supranational mobility project affects international relocations compared with potential countries of destination that offer less welcoming contexts of reception. 
Second, the number of Germans living abroad is rather high compared to other OECD countries, but their share in proportion to the population size in Germany is average. Constructed on the basis of census data and major national household surveys, the Database on Immigrants in OECD Countries (DIOC) provides some indications about the volume of emigration from all OECD member states (Dumont and Lemaître 2008). In the years 2015/16-the newest data available-almost 45 million emigrants from OECD member states lived in one of the other OECD countries (see Fig. 1.1). This corresponds to a total of $4 \%$ of the population over 15 years of age, who thus live outside their country of birth. While economic prosperity makes emigration less of a necessity for a successful career, generous visa-admissions around the globe and comparatively low visa costs make emigration from rich countries comparatively easy (Mau et al. 2015; Recchi et al. 2020). The 3.8 million German emigrants constitute the fourth largest origin group behind Mexican, Polish, and British emigrants but its emigration rate-the proportion of emigrants in relation to the total population in the country of origin-of $5.1 \%$ is just about the average of all OECD member states and resembles that of Italy, Canada, and Finland. In addition to Germany's representative role as one of the economically highly developed welfare states, the broad indicators on the international mobility of the German population reviewed above also make Germany a suitable case study.

A third reason is of more practical relevance. It concerns the general requirements for setting up a specialised data infrastructure about the internationally mobile population in Germany. Based on information from Germany's population register, the average yearly number of German citizens moving abroad during recent years was about 132,000 and the corresponding number of remigrants was 111,000

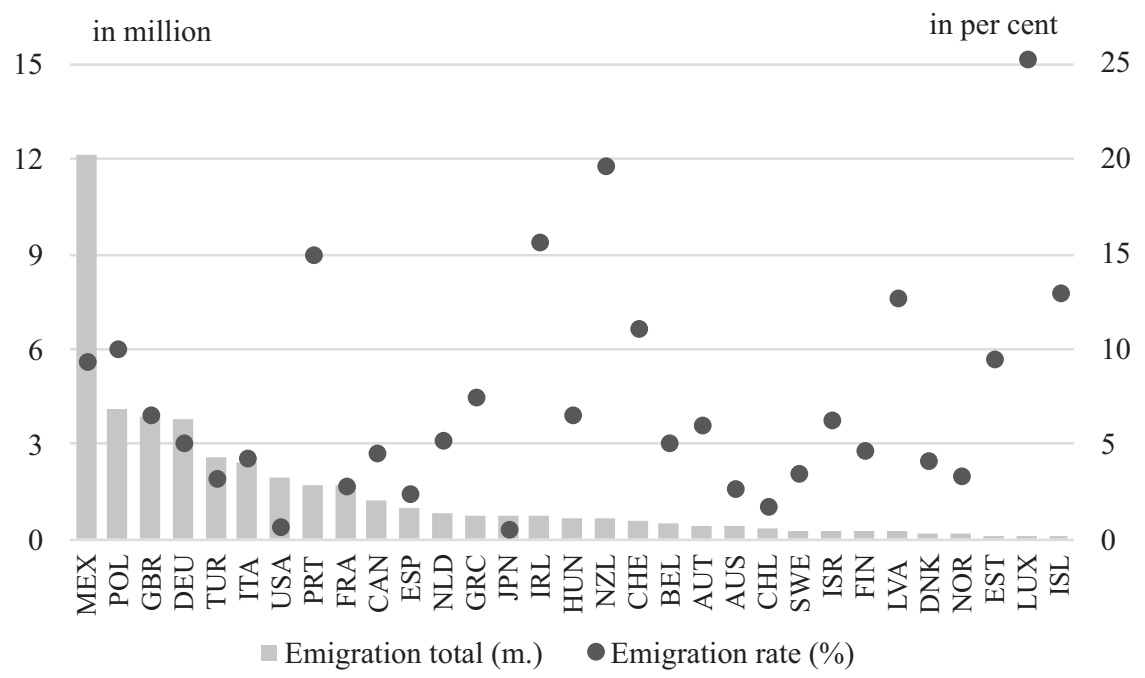

Fig. 1.1 Emigrated population (in million) and emigration rates (in per cent) by country of birth of emigrants for the years 2015/16. (Source: OECD DIOC 2015/16; authors' calculation and presentation) 
(cf. Ette and Erlinghagen 2021 in this volume). Those substantial numbers of the internationally mobile population in Germany provide a basis for sampling an otherwise rare population. Furthermore, the population register in Germany not only allows us to identify internationally mobile German citizens, but also provides the necessary information to contact them after their return to Germany and after their movement abroad to their destination countries (cf. Ette et al. 2021b in this volume).

Fourth, Germany is a country where demographic developments make monitoring the international mobility of its own population a political priority. Most economically highly developed countries can be described as ageing societies caused by declining fertility and increasing life expectancy (e.g. Lutz and Kebede 2018; Zeman et al. 2018). Two central consequences concern the organisation of health care and the demand for skilled labour. Specifically, labour shortages in the care sector and high costs for elder care may be potential push factors for the migration of older people. As for labour markets, the combination of demographic and technological change has boosted demand for qualified labour in personal services and in particular for highly qualified labour in business services (Oesch and Rodríguez Menés 2011). Although women's increased labour market integration partly responds to this demand increase, skills shortages remain a concern in many economically highly developed countries-but in particular for Germany due to its demographic development. The emigration of its own population potentially aggravates both problems.

\subsection{Outline of the Book}

This volume sheds light on international migration from economically highly developed welfare states. Based on the example of Germany, it concentrates on the consequences temporary or putatively permanent stays abroad have for the life courses of internationally mobile individuals. Aiming at the systematic and comprehensive analysis of the individual consequences of migration, the volume forgoes traditional dimensions of structural, social, and cultural assimilation or integration (e.g. Esser 1980; Gordon 1964). In line with classical conceptualisations of social inequality (e.g. Hradil 2005; Savage et al. 2005), it focuses instead on four dimensions of the life course that already structure many analyses about the individual consequences of regional migration within nation-states (e.g. Schneider and Meil 2008; Viry and Kaufmann 2015): (1) employment and social mobility, (2) partner and family, (3) wellbeing and health, and (4) friends and social integration. Applying these general dimensions of the life course to the realm of migration also helps us transcend migration research's overwhelming focus on the integration of ethnic groups into host societies as primordial entities (Wimmer 2009) and provides empirical illustrations for a "strategy to 'de-migranticise' research on migration and integration" (Dahinden 2016, p. 2214).

Following the aims of this volume, the first section of this book consists of two chapters. Whereas this chapter presents the conceptual framework of the volume, 
Chap. 2 discusses its empirical foundation. Ette et al. (2021b) present the German Emigration and Remigration Panel Study (GERPS) as a new data infrastructure for analysing the individual consequences of international migration. The authors argue that the origin-based sampling strategy and the push-to-web surveying strategy represent promising templates for other migrant surveys.

The second section of the book focuses on international migration from economically highly developed welfare states. Addressing the lack of information about emigration from these countries, the following chapters provide basic information about internationally mobile people. Why do they leave a country offering good economic opportunities, high living standards, and a well-established welfare state? Chap. 3 by Ette and Erlinghagen (2021) sets the scene for this part of the volume. They provide an historical overview of Germany as a country of emigration and present basic demographic patterns of international German migrants. Whereas the volume of emigration of German citizens has been slowly increasing over the past three decades, they highlight the fact that net migration has remained rather stable. The economic and non-economic determinants of international migration decisions are at the centre of the article by Ette and Witte (2021) in Chap. 4. Focusing on a comparison between emigrants and non-migrants, they model the emigration decision, whereas the contrast between remigrants and emigrants provides information about the remigration decision to provide individual level information about a potential 'brain drain' from Germany. Extending neo-classical economic approaches to migration, Lübke et al. (2021) focus on psychological determinants of migration. In their analysis, they investigate individual risk attitudes as preconditions for migration as well as for the choice of the destination country (Chap. 5). Finally, Ette et al. (2021a) focus on the permanence of emigration from economically highly developed welfare states. Applying a life-course approach, they highlight the interrelations between different life-course domains and the intentions of German emigrants to settle permanently abroad, planning to return, or being undecided about the further course of their migration project (Chap. 6).

Part III of this volume is concerned with two central dimensions of social mobility research: the intra- and the intergenerational mobility of German emigrants. Favourable conditions in the German labour market compared to other countries imply that emigration may hardly improve individual labour market outcomes. Yet recent theoretical propositions suggest that the individual experience of international migration could be an asset that improves labour market outcomes. Witte and Guedes Auditor (2021) deal with German emigrants' wage changes that are suggestive of intragenerational mobility and demonstrate a clearly positive average wage change after emigration compared with non-migrants (Chap. 7). Witte et al. (2021) investigate the social background of German emigrants' in terms of their parents' education and social class and analyse the consequences of spatial mobility for intergenerational social mobility of emigrants compared to non-migrants (Chap. 8).

Part IV investigates the nexus of global lives with partnership and family status. Unless migration is a move to unite couple households, it puts families and partnerships under stress. Erlinghagen (2021) deals with the migration motives, timing, and outcomes of internationally mobile couples (Chap. 9). He investigates the 
phenomenon of trailing partners and documents not only traditional gender patterns of emigrating couples but also the decreasing life satisfaction of trailing women. Chap. 10 provides analyses of partnership breakup patterns among German emigrants and remigrants and presents findings on separations in the course of migration (Baykara-Krumme et al. 2021). Their findings suggest that the risk of partnership dissolution is particularly increased by non-egalitarian and non-synchronised migrations of couples.

Part V deals with German migrants' health and wellbeing. According to classical human capital theories, migrants are supposedly healthier than non-migrants. This mechanism of self-selection could, however, be counterbalanced by stressors that accrue from migration. With regard to subjective wellbeing, Guedes Auditor and Erlinghagen (2021) analyse possible impacts of emigration on overall life satisfaction (Chap. 11). Chapter 12 yields results concerning interrelations between international mobility and self-rated health status (Stawarz et al. 2021). They test the healthy migrant effect, well known from international migration in other geographic contexts, for the case of German emigrants and remigrants and document significant self-selection with increasing age at migration.

Part VI of this volume explores German migrants' friends and social participation. Earlier research on international German migrants suggests that emigration lowers satisfaction with social bonds and causes a loss of social capital after migration (Engler et al. 2015). Whereas Mansfeld (2021) presents results on emigrants' contact with friends in Germany and its impact on subjective wellbeing (Chap. 13), Décieux and Mörchen (2021) investigate the development of friendship network size shortly after emigration (Chap. 14). In Chap. 15, Décieux and Murdock (2021) analyse identity constructs of German international migrants. Their findings indicate that identification with host countries is already rather strong shortly after arrival.

Finally, Part VII of this volume analyses different aspects of the research methods applied in the German Emigration and Remigration Panel Study (GERPS). Genoni et al. (2021) analyse a methodological experiment offering potential participants an alternative survey mode alongside computer assisted web interviewing (CAWI). They concentrate on the effect of the push-to-web design on unitnonresponse and panel participation, highlighting a generally high level of acceptance of an online surveying mode across all age groups in this internationally mobile population (Chap. 16). The final Chap. 17 by Décieux (2021) offers methodological findings on the potential of paradata analysis in GERPS by analysing differences in response behaviour according to device use-a crucial feature of surveys of highly mobile populations.

The articles in this volume demonstrate that the destination-origin-migration approach results in a theoretically broad and empirically rich picture of the individual consequences of international migration. Whereas the context of reception in the destination countries was only touched upon in a few chapters (e.g. Chaps. 3, 5, $6,12,13$ and 15), the bulk focused on the origin and migration perspective. In particular Chaps. 4, 5, 7, 8, 11, 12, and 14 address the origin perspective and focus on the comparison between the internationally mobile and the non-mobile stayers. The 
life course perspective instead is at the centre of Chaps. 6, 7, 8, 9, 10, 12, and 14, which focus in particular on the dynamic development of global lives following an international migration event.

Methodologically, most articles refer to cross-sectional information collected throughout the first wave of this panel survey, which includes information about the living situation before migration as well as at the time of the interview shortly after the migration event. Despite the timeliness of the data, three chapters (Chaps. 8, 10, and 14) apply information from the second wave, which was conducted during the summer of 2019. Whereas the results in all chapters rely on multivariate statistical methods, some work strictly within the counterfactual framework for estimating causal treatment effects (Chaps. 7, 8 and 11).

Overall, the studies in this volume demonstrate GERPS's potential for further comparative and longitudinal analyses. This potential will increase with the publication of subsequent survey waves and provide additional information to substantiate causal claims about the consequences of international migration. Confronted with the fragmented state of research about the international mobility of populations in economically highly developed welfare states, this volume hopes to make a contribution by addressing several imminent research questions in this field.

\section{References}

Ackers, L., \& Gill, B. (2008). Moving people and knowledge. Scientific mobility in an enlarging European Union. Cheltenham: Edward Elgar.

Adick, C., Maletzky, M., Pries, L., \& Gandlgruber, B. (Eds.). (2014). Cross-border staff mobility. A comparative study of profit and non-profit organisations. London: Palgrave Macmillan.

Alba, R., \& Nee, V. (1997). Rethinking assimilation theory for a new era of immigration. International Migration Review, 31(4), 826-874.

Amelina, A., \& Faist, T. (2012). De-naturalizing the national in research methodologies: Key concepts of transnational studies in migration. Ethnic and Racial Studies, 35(10), 1707-1724.

Andresen, M., Biemann, T., \& Pattie, M. W. (2015). What makes them move abroad? Reviewing and exploring differences between self-initiated and assigned expatriation. The International Journal of Human Resource Management, 26(7), 932-947.

Baizán, P., Beauchemin, C., \& González-Ferrer, A. (2014). An origin and destination perspective on family reunification: The case of Senegalese couples. European Journal of Population, $30(1), 65-87$.

Baykara-Krumme, H., Erlinghagen, M., \& Mansfeld, L. (2021). Disruption of family lives in the course of migration: 'Tied migrants' and partnership breakup patterns among German (r) emigrants. In M. Erlinghagen, A. Ette, N. F. Schneider, \& N. Witte (Eds.), The global lives of German migrants. Consequences of international migration across the life course. Cham: Springer.

Beck, S., \& Weinar, A. (2017). Mobile French citizens and La Mère-Patrie: Emigration and diaspora policies in France. In A. Weinar (Ed.), Emigration and diaspora policies in the age of mobility (pp. 85-99). Cham: Springer.

Beck, U. (2009). Jenseits von Klasse und Nation: Individualisierung und Transnationalisierung sozialer Ungleichheiten. Soziale Welt, 59(4), 301-325.

Benson, M., \& O'Reilly, K. (2009). Migration and the search for a better way of life: A critical exploration of lifestyle migration. The Sociological Review, 57(4), 608-625. 
Berry, J. W. (1997). Immigration, acculturation, and adaptation. Applied Psychology, 46(1), 5-34.

Bilecen, B., \& van Mol, C. (2017). Introduction: International academic mobility and inequalities. Journal of Ethnic and Migration Studies, 43(8), 1241-1255.

Boswell, C., \& Geddes, A. (2011). Migration and mobility in the European Union. Basingstoke: Palgrave Macmillan.

Braun, M., and Arsene, C. (2009). The demographics of movers and stayers in the European Union. Pioneers of European Integration. Citizenship and Mobility in the EU, Cheltenham, Edward Elgar.

Carlson, S. (2013). Becoming a Mobile student-A processual perspective on German degree student mobility. Population, Space and Place, 19(2), 168-180.

Castles, S., de Haas, H., \& Miller, M. J. (2014). The age of migration. International population movements in the modern world (5th ed.). Basingstoke: Palgrave Macmillan.

Constant, A. F., \& Zimmermann, K. F. (2011). Circular and repeat migration: Counts of exits and years away from the host country. Population Research and Policy Review, 30(4), 495-515.

Cresswell, T. (2006). On the move: Mobility in the modern western world. New York: Taylor \& Francis.

Dahinden, J. (2016). A plea for the 'de-migranticization' of research on migration and integration. Ethnic and Racial Studies, 39(13), 2207-2225.

Dashefsky, A., \& Woodrow-Lafield, K. (2020). Americans abroad: A comparative study of emigrants from the United States. Dordrecht: Springer.

Décieux, J. P. (2021). Is there more than the answer to the question? Device use and completion time as indicators for selectivity bias and response convenience in online surveys. In M. Erlinghagen, A. Ette, N. F. Schneider, \& N. Witte (Eds.), The global lives of German migrants. Consequences of international migration across the life course. Cham: Springer.

Décieux, J. P., \& Mörchen, L. (2021). Emigration, friends, and social integration: The determinants and development of friendship network size after arrival. In M. Erlinghagen, A. Ette, N. F. Schneider, \& N. Witte (Eds.), The global lives of German migrants. Consequences of international migration across the life course. Cham: Springer.

Décieux, J. P., \& Murdock, E. (2021). Sense of belonging: Predictors for host country attachment among German emigrants. In M. Erlinghagen, A. Ette, N. F. Schneider, \& N. Witte (Eds.), The global lives of German migrants. Consequences of international migration across the life course. Cham: Springer.

Diehl, C., Lubbers, M., Mühlau, P., \& Platt, L. (2015). Starting out: New migrants' socio-cultural integration trajectories in four European destinations. Ethnicities, 16(2), 157-179.

Diez Medrano, J. (2014). The socio-economic returns of fluency in English as a foreign language. In J. Gerhards, S. Hans, \& S. Carlson (Eds.), Globalisierung, Bildung und grenzüberschreitende Mobilität (pp. 239-257). Wiesbaden: Springer VS.

DiPrete, T. A., \& Forristal, J. D. (1994). Multilevel models: Methods and substance. Annual Review of Sociology, 20(1), 331-357.

Dumont, J.-C., \& Lemaître, G. (2008). Counting foreign-born and expatriates in OECD countries: A new perspective. In J. Raymer \& F. Willekens (Eds.), International migration in Europe. Data, models and estimates (pp. 11-40). John Wiley \& Sons.

Elder, G. H. (2003). The life course in time and place. In W. R. Heinz \& V. W. Marshall (Eds.), Social dynamics of the life course: Transitions, institutions, and interrelations (pp. 57-71). New York: de Gruyter.

Engbersen, G., Snel, E., \& de Boom, J. (2010). 'A van full of Poles': Liquid migration from central and Eastern Europe. In R. Black, G. Engbersen, M. Okólski, \& C. Panțîru (Eds.), A continent moving west? EU enlargement and labour migration from central and Eastern Europe (pp. 115-140). Amsterdam University Press.

Engler, M., Erlinghagen, M., Ette, A., Sauer, L., Scheller, F., Schneider, J., \& Schultz, C. (2015). International Mobil: Motive, Rahmenbedingungen und Folgen der Aus-und Rückwanderung deutscher Staatsbürger. Berlin: Sachverständigenrat deutscher Stiftungen für Integration und Migration (SVR). 
Erlinghagen, M. (2011). Nowhere better than here? The subjective well-being of German emigrants and remigrants. Comparative Population Studies, 36(4), 899-926.

Erlinghagen, M. (2021). Migration motives, timing, and outcomes of internationally mobile couples. In M. Erlinghagen, A. Ette, N. F. Schneider, \& N. Witte (Eds.), The global lives of German migrants. Consequences of international migration across the life course. Cham: Springer.

Esser, H. (1980). Aspekte der Wanderungssoziologie. Assimilation und Integration von Wanderern, ethnischen Gruppen und Minderheiten. Eine handlungstheoretische Analyse. Darmstadt, Neuwied: Luchterhand.

Ette, A., \& Sauer, L. (2010). Auswanderung aus Deutschland. Daten und Analysen zur internationalen Migration deutscher Staatsbürger. Wiesbaden: VS Verlag.

Ette, A., Décieux, J. P., Erlinghagen, M., Guedes Auditor, J., Sander, N., Schneider, N. F., \& Witte, N. (2021b). Surveying across borders: The experiences of the German emigration and remigration panel study. In M. Erlinghagen, A. Ette, N. F. Schneider, \& N. Witte (Eds.), The global lives of German migrants. Consequences of international migration across the life course. Cham: Springer.

Ette, A., \& Erlinghagen, M. (2021). Structures of German emigration and remigration: Historical developments and demographic patterns. In M. Erlinghagen, A. Ette, N. F. Schneider, \& N. Witte (Eds.), The global lives of German migrants. Consequences of international migration across the life course. Cham: Springer.

Ette, A., Sauer, L., \& Fauser, M. (2021a). Settlement or return? The intended permanence of emigration from Germany across the life course. In M. Erlinghagen, A. Ette, N. F. Schneider, \& N. Witte (Eds.), The global lives of German migrants. Consequences of international migration across the life course. Cham: Springer.

Ette, A., \& Witte, N. (2021). Brain drain or brain circulation? Economic and non-economic factors driving the international migration of German citizens. In M. Erlinghagen, A. Ette, N. F. Schneider, \& N. Witte (Eds.), The global lives of German migrants. Consequences of international migration across the life course. Cham: Springer.

European Commission. (2019). Erasmus+ annual report 2018. Luxembourg: Publications Office of the European Union.

Faist, T. (2016). Cross-border migration and social inequalities. Annual Review of Sociology, 42(5), 1-24.

Fauser, M. (2020). Mobile citizenship. Spatial privilege and the transnational lifestyles of senior citizens. London: Routledge.

Favell, A. (2008). Eurostars and Eurocities. Free movement and mobility in an integrating Europe. Oxford: Blackwell.

Favell, A., Feldblum, M., \& Smith, M. P. (2007). The human face of global mobility: A research agenda. Society, 44(2), 15-25.

Findlay, A. M., \& Li, F. L. N. (1998). A migration channels approach to the study of professionals moving to and from Hong Kong. International Migration Review, 32(3), 682-703.

Findlay, A., McCollum, D., Coulter, R., \& Gayle, V. (2015). New mobilities across the life course: A framework for analysing demographically linked drivers of migration. Population, Space and Place, 21(4), 390-402.

FitzGerald, D. (2014). The sociology of international migration. In C. B. Brettell \& J. F. Hollifield (Eds.), Migration theory: Talking across disciplines. Routledge.

FitzGerald, D. (2012). A comparativist manifesto for international migration studies. Ethnic and Racial Studies, 35(10), 1725-1740.

Fuller, S. (2015). Do pathways matter?: Linking early immigrant employment sequences and later economic outcomes: Evidence from Canada. International Migration Review, 49(2), 355-405.

Geist, C., \& McManus, P. A. (2008). Geographical mobility over the life course: Motivations and implications. Population, Space and Place, 14(4), 283-303.

Genoni, A., Décieux, J. P., Ette, A., \& Witte, N. (2021). Setting up probability-based online panels of migrants through push-to-web recruitment: Methodological challenges and lessons learned from the German emigration and remigration panel study (GERPS). In M. Erlinghagen, A. Ette, 
N. F. Schneider, \& N. Witte (Eds.), The global lives of German migrants. Consequences of international migration across the life course. Cham: Springer.

Gerhards, J., \& Hans, S. (2013). Transnational human capital, education, and social inequality. Analyses of international student exchange. Zeitschrift für Soziologie, 42(2), 99-117.

Gerhards, J., Hans, S., Carlson, S., \& Drewski, D. (2017). The globalisation of labour markets: A content Analy sis of the demand for transnational human capital in job advertisements. Soziale Welt, 68(1), 25-44.

Gordon, M. M. (1964). Assimilation in American life. The role of race, religion, and national origins. New York: Oxford University Press.

Guedes Auditor, J., \& Erlinghagen, M. (2021). The happy migrant? Emigration and its impact on social wellbeing. In M. Erlinghagen, A. Ette, N. F. Schneider, \& N. Witte (Eds.), The global lives of German migrants. Consequences of international migration across the life course. Cham: Springer.

Guveli, A., Ganzeboom, H. B. G., Platt, L., Nauck, B., Baykara-Krumme, H., Eroğlu, Ş., Bayrakdar, S., Sözeri, E. K., \& Spierings, N. (2016). Intergenerational consequences of migration. Socio-economic, family and cultural patterns of stability and change in Turkey and Europe. Basingstoke: Palgrave Macmillan.

Habti, D., \& Elo, M. (2019). Global mobility of highly skilled people. Cham: Springer International Publishing.

Hainmueller, J., \& Hiscox, M. J. (2010). Attitudes toward highly skilled and low-skilled immigration: Evidence from a survey experiment. American Political Science Review, 104(1), 61-84.

Harrington, B., \& Seabrooke, L. (2020). Transnational professionals. Annual Review of Sociology, $46(1), 1-19$.

Hayes, M. (2014). 'We gained a lot over what we would have had': The geographic arbitrage of North American lifestyle migrants to Cuenca, Ecuador. Journal of Ethnic and Migration Studies, 40(12), 1953-1971.

Heath, A. F., \& Cheung, S. Y. (2007). The comparative study of ethnic minority disadvantage. In A. F. Heath \& S. Y. Cheung (Eds.), Unequal chances. Ethnic minorities in Western labour market (pp. 1-44). New York: Oxford University Press.

Helbling, M. (2011). Why Swiss-Germans dislike Germans. Opposition to culturally similar and highly skilled immigrants. European Societies, 13(1), 5-27.

Hradil, S. (2005). Soziale Ungleichheit in Deutschland (8th ed.). Wiesbaden: VS Verlag.

Hugo, G. J. (2006). An Australian Diaspora? International Migration, 44(1), 105-133.

Jacob, M., Kühhirt, M., \& Rodrigues, M. (2019). Labour market returns to Graduates' International experience: Exploring cross-country variation in Europe. European Sociological Review, 35(4), 491-505.

Kalton, G., \& Anderson, D. W. (1986). Sampling rare populations. Journal of the Royal Statistical Society. Series A (General), 149(1), 65-82.

Kaufmann, V., Bergman, M. M., \& Joye, D. (2004). Motility: Mobility as capital. International Journal of Urban and Regional Research, 28(4), 745-756.

Kauppinen, I., Nikolka, T., \& Poutvaara, P. (2019). Self-selection and motivations of emigrants from a welfare state. München: Ifo Institute for Economic Research.

King, R., \& Williams, A. M. (2018). Editorial introduction: New European youth mobilities. Population, Space and Place, 24(1), e2121.

Klekowski von Koppenfels, A. (2014). Migrants or expatriates? Americans in Europe. Basingstoke: Palgrave.

Kley, S. (2011). Explaining the stages of migration within a life-course framework. European Sociological Review, 27(4), 469-486.

Kogan, I., \& Weißmann, M. (2013). Immigrants' initial steps in Germany and their later economic success. Advances in Life Course Research, 18(3), 185-198.

Latcheva, R., \& Herzog-Punzenberger, B. (2011). Integration revisited. Zur Dynamik und Kontextabhängigkeit individueller Integrationsverläufe am Beispiel von MigrantInnen der ersten Generation in Wien. Österreichische Zeitschrift für Soziologie, 36(3), 3-27. 
Lauterbach, W., Ette, A., \& Waibel, S. (2017). Transnationale Bildungswanderungen zur Höherqualifizierung. In E. Schlemmer, A. Lange, \& L. Kuld (Eds.), Handbuch Jugend im demografischen Wandel. Weinheim: Beltz: 188-208 (pp. 188-208). Weinheim: Beltz.

Lavrakas, P. (2008). Encyclopedia of survey research methods. Thousand Oaks, CA: SAGE Publications.

Levitt, P., \& Jaworsky, B. N. (2007). Transnational migration studies: Past developments and future trends. Annual Review of Sociology, 33(1), 129-156.

Lübke, C., Décieux, J. P., Erlinghagen, M., \& Wagner, G. G. (2021). Comparing the risk attitudes of internationally mobile and non-mobile Germans. In M. Erlinghagen, A. Ette, N. F. Schneider, $\& \mathrm{~N}$. Witte (Eds.), The global lives of German migrants. Consequences of international migration across the life course. Cham: Springer.

Luthra, R., Soehl, T., \& Waldinger, R. (2018). Reconceptualizing context: A multilevel model of the context of reception and second-generation educational attainment. International Migration Review, 52(3), 898-928.

Lutz, W., \& Kebede, E. (2018). Education and health: Redrawing the Preston curve. Population and Development Review, 44(2), 343-361.

Mansfeld, L. (2021). Out of sight, out of mind? Frequency of emigrants' contact with friends in Germany and its impact on subjective well-being. In M. Erlinghagen, A. Ette, N. F. Schneider, $\& \mathrm{~N}$. Witte (Eds.), The global lives of German migrants. Consequences of international migration across the life course. Cham: Springer.

Mau, S., Gülzau, F., Laube, L., \& Zaun, N. (2015). The global mobility divide: How visa policies have evolved over time. Journal of Ethnic and Migration Studies, 41(8), 1192-1213.

Mayer, K. U. (2009). New directions in life course research. Annual Review of Sociology, 35, 413-433.

McKenzie, D., Stillman, S., \& Gibson, J. (2010). How important is selection? Experimental vs. non-experimental measures of the income gains from migration. Journal of the European Economic Association, 8(4), 913-945.

McNulty, Y., \& Brewster, C. (2017). The concept of business expatriates. In Y. McNulty \& J. Selmer (Eds.), Research handbook of expatriates (pp. 21-60). Cheltenham: Edward Elgar.

Morgan, S. L., \& Winship, C. (2015). Counterfactuals and causal inference: Methods and principles for social research. New York: Cambridge University Press.

Mulder, C. H. (1993). Migration dynamics: A life course approach. Amsterdam: Thesis Publishers.

Nikolova, M., \& Graham, C. (2015). In transit: The Well-being of migrants from transition and post-transition countries. Journal of Economic Behaviour and Organization, 112, 164-186.

Nohl, A.-M., Schittenhelm, K., Schmidtke, O., \& Weiß, A. (2014). Work in transition: Cultural capital and highly skilled Migrants' passages into the labour market. University of Toronto Press.

Norris, P., \& Inglehart, R. F. (2012). Muslim integration into Western cultures: Between origins and destinations. Political Studies, 60(2), 228-251.

OECD. (2019). Society at a Glance 2019. Paris: OECD Publishing.

Oesch, D., \& Rodríguez Menés, J. (2011). Upgrading or polarization? Occupational change in Britain, Germany, Spain and Switzerland, 1990-2008. Socio-Economic Review, 9(3), 503-531.

Peixoto, J. (2001). The international mobility of highly skilled workers in transnational corporations: The macro and micro factors of the organizational migration of cadres. International Migration Review, 35(4), 1030-1053.

Pohlmann, M. (2009). Globale ökonomische Eliten? Eine Globalisierungsthese auf dem Pürfstand der Emperie. Kölner Zeitschrift für Soziologie und Sozialpsychologie, 61(4), 513-534.

Pöllmann, A. (2013). Intercultural capital: Toward the conceptualization, operationalization, and empirical investigation of a rising marker of sociocultural distinction. SAGE Open, 3(2), 1-7.

Portes, A., \& Zhou, M. (1993). The new second generation: Segmented assimilation and its variants among post 1965 immigrant youth. Annals of the American Academy of Political and Social Sciences, 530, 74-96. 
Prandner, D., and Weichbold, M. (2019). Building a Sampling Frame for Migrant Populations via an Onomastic Approach - Lesson learned from the Austrian Immigrant Survey 2016. Survey Methods: Insights from the Field.

Pries, L. (2010). Transnationalisierung: Theorie und Empirie grenzüberschreitender Vergesellschaftung. Wiesbaden: Springer VS.

Recchi, E. (ed.). (2014). The Europeanisation of Everyday Life: Cross-Border Practices and Transnational Identifications among EU and Third-Country Citizens-Final Report: MISC.

Recchi, E. (2015). Mobile Europe: The theory and practice of free movement in the EU. Basingstoke: Palgrave Macmillan.

Recchi, E., Deutschmann, E., Gabrielli, L., \& Kholmatova, N. (2020). Assessing visa costs on a global scale. San Domenico di Fiesole: Migration Policy Centre.

Recchi, E., \& Favell, A. (Eds.). (2009). Pioneers of European integration. Citizenship and mobility in the EU. Cheltenham: Edward Elgar.

Rüger, H., Ruppenthal, S., Fliege, H., Hillmann, J., Kaukal, M., Bellinger, M. M., \& Schneider, N. F. (2013). Mobilitätskompetenzen im Auswärtigen Dienst. . Risiken und protektive Faktoren bei der Bewältigung der Auslandsrotation. Würzburg: Ergon.

Savage, M., Warde, A., \& Devine, F. (2005). Capitals, assets, and resources: Some critical issues. The British Journal of Sociology, 56(1), 31-47.

Scheibelhofer, E. (2018). Shifting migration aspirations in second modernity. Journal of Ethnic and Migration Studies, 44(6), 999-1014.

Schneider, N. F., Limmer, R., \& Ruckdeschel, K. (2002). Mobil, flexibel, gebunden: Familie und Beruf in der mobilen Gesellschaft. Frankfurt am Main: Campus Verlag.

Schneider, N. F., \& Meil, G. (Eds.). (2008). Mobile living across Europe I. relevance and diversity of job-related spatial mobility in six European countries. Opladen, Farmington Hills: Barbara Budrich.

Snijders, T. A. B., \& Bosker, R. J. (2011). Multilevel analysis. An introduction to basic and advanced multilevel Modeling. London: SAGE Publications.

Stawarz, N., Ette, A., \& Rüger, H. (2021). Healthy migrants? Comparing subjective health of German emigrants, remigrants and non-migrants. In M. Erlinghagen, A. Ette, N. F. Schneider, $\&$ N. Witte (Eds.), The global lives of German migrants. Consequences of international migration across the life course. Cham: Springer.

UIS. (2020). Outbound internationally mobile tertiary students studying abroad. Montreal: UNESCO Institute for Statistics.

UN. (2019). International migrant stock 2019 (United Nations database, POP/DB/MIG/Stock/ Rev.2019). New York: United Nations, Population Division.

Urry, J. (2007). Mobilities. Cambridge: Polity Press.

van Dalen, H. P., \& Henkens, K. (2013). Explaining emigration intentions and behaviour in the Netherlands, 2005-10. Population Studies, 67(2), 225-241.

Viry, G., \& Kaufmann, V. (Eds.). (2015). High mobility in Europe: Work and personal life. London: Palgrave Macmillan UK.

Weiß, A. (2005). The Transnationalization of social inequality: Conceptualizing social positions on a world scale. Current Sociology, 53(4), 707-728.

Willekens, F., Massey, D., Raymer, J., \& Beauchemin, C. (2016). International migration under the microscope. Science, 352(6288), 897-899.

Wimmer, A. (2009). Herder's heritage and the boundary-making approach: Studiyng ethnicity in immigrant societies. Sociological Theory, 27(3), 244-270.

Windzio, M., and Aybek, C. M. (2015). Marriage, norm orientation and leaving the parental home: Turkish immigrant and native families in Germany.

Wingens, M., Windzio, M., de Valk, H., \& Aybek, C. (Eds.). (2011). A life-course perspective on migration and integration. Heidelberg, London, New York: Springer.

Witte, N., \& Guedes Auditor, J. (2021). Affluent lives beyond the border? Individual wage change through migration. In M. Erlinghagen, A. Ette, N. F. Schneider, \& N. Witte (Eds.), The global 
lives of German migrants. Consequences of international migration across the life course. Cham: Springer.

Witte, N., Pollak, R., \& Ette, A. (2021). Social origins of German emigrants: Maintaining social status by international mobility? In M. Erlinghagen, A. Ette, N. F. Schneider, \& N. Witte (Eds.), The global lives of German migrants. Consequences of international migration across the life course. Cham: Springer.

Wright, M., \& Bloemraad, I. (2012). Is there a trade-off between multiculturalism and sociopolitical integration? Policy regimes and immigrant incorporation in comparative perspective. Perspectives on Politics, 10(1), 77-95.

Zeman, K., Beaujouan, É., Brzozowska, Z., \& Sobotka, T. (2018). Cohort fertility decline in low fertility countries: Decomposition using parity progression rates. Demographic Research, 38 , 651-690.

Zuccotti, C. V., Ganzeboom, H. B. G., \& Guveli, A. (2015). Has migration been beneficial for migrants and their children? Comparing social mobility of Turks in Western Europe, Turks in Turkey, and Western European natives. International Migration Review, 51(1), 97-126.

Open Access This chapter is licensed under the terms of the Creative Commons Attribution 4.0 International License (http://creativecommons.org/licenses/by/4.0/), which permits use, sharing, adaptation, distribution and reproduction in any medium or format, as long as you give appropriate credit to the original author(s) and the source, provide a link to the Creative Commons license and indicate if changes were made.

The images or other third party material in this chapter are included in the chapter's Creative Commons license, unless indicated otherwise in a credit line to the material. If material is not included in the chapter's Creative Commons license and your intended use is not permitted by statutory regulation or exceeds the permitted use, you will need to obtain permission directly from the copyright holder.

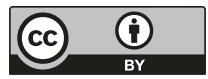

